\title{
Nitrogen content in plant biomass from subterranean clover (Trifolium subterraneum L.) and cocksfoot (Dactylis glomerata L.) grown under different inorganic nitrogen supply
}

\author{
Viliana Vasileva $\cdot$ Konstantina Kocheva $\cdot$ Janet Mincheva \\ Georgi Georgiev $\cdot$ Anna Ilieva $\cdot$ Claudio Porqueddu
}

\begin{abstract}
Summary: Nitrogen content in plant biomass yield of subterranean clover (Trifolium subterraneum L.) and cocksfoot (Dactylis glomerata L.) was determined as related to the different concentrations of nitrogen supply. Plants were grown sole and in mixture as symbiotrophic or heterotrophic cultures under controlled mineral elements concentration in the media and inoculation with rhyzobial strain. Two concentrations of inorganic nitrogen were tested: $0.125 \mathrm{mM}$ (N1) and $1.25 \mathrm{mM}(\mathrm{N} 2)$. Experimental variants: subterranean clover $(100 \%)+\mathrm{N} 1$; subterranean clover $(100 \%)+$ $\mathrm{N} 2$; cocksfoot $(100 \%)+\mathrm{N} 1$; cocksfoot $(100 \%)+\mathrm{N} 2$; subterranean clover + cocksfoot $(50: 50 \%)+\mathrm{N} 1$; subterranean clover + cocksfoot $(50: 50 \%)+\mathrm{N} 2$. Inorganic nitrogen concentration had greater effect on shoot yield nitrogen content than on root yield nitrogen content for both crops. Nitrogen content in whole plant biomass yield of subterranean clover grown either sole or in mixture with cocksfoot was almost three times greater under high nitrogen concentration. Nitrogen use efficiency was highest in the mixture.
\end{abstract}

Keywords: biomass, cocksfoot, Dactylis glomerata, mixtures, nitrogen, subterranean clover, Trifolium subterraneum

\section{Introduction}

Interest towards mixtures based on growing legume and grasses has been rising in recent years due to their role in development of sustainable and ecologically pure agriculture (Pypers et al. 2005, Luscher et al. 2014, Kusvuran et al. 2014). The legume component in such mixture contributes to amelioration of the balance of mineral elements in the soil and especially for the increase of nitrogen in the system due to its ability for utilization of the process of symbiotic nitrogen fixation (Jarvis \& Barraclough 1991, Scholefield \& Titchen 1995, Peeters et al. 2006, Pozdisek et al. 2011). Nitrogen derived from biological nitrogen fixation is the main source of

V. Vasileva* · A. Ilieva

Institute of forage crops, 89 Gen. Vladimir Vazov St, 5800 Pleven, Bulgaria

e-mail: viliana.vasileva@gmail.com

K. Kocheva $\cdot J$. Mincheva $\cdot$ G. Georgiev

Institute of Plant Physiology and Genetics, Bulgarian Academy of Sciences, Academy Georgi Bonchev St, B1. 21, 1113 Sofia, Bulgaria

C. Porqueddu

CNR-ISPAAM, Traversa la Crucca 3, località Baldinca, 07100 Sassari, Italy nitrogen utilized directly by plants (Graham 2008, Solomon et al. 2012).

Constant climate changes force forage crops and mixtures to adapt to the altered conditions and require better efficiency of resource utilization by mixtures (Lelièvre \& Volaire 2009). At present, the main interest is directed towards more drought resistant and drought tolerant components. Legume species that can provide self-sowing and persist continuously in the sward become of practical importance (Carneiro 1999).

Subterranean clover (Trifolium subterraneum L.) is an annual drought resistant ephemeral legume with winter-spring type of development and ability for self-sowing (Yakimova \& Yancheva 1986, Piano et al. 1996, Frame et al. 1998). As a nitrogen fixing crop, it is widely distributed in pastures of temperate climatic regions of Middle and Northern Europe and America (Frame et al. 1998, Pecetti \& Piano 1998 2002). It has a number of advantages in comparison to white clover (Mihovski \& Goranova 2007). A marked winter resistance, effective utilization of autumnwinter soil moisture, successful seed formation and self-sowing at the end of spring allow subterranean clover to avoid summer droughts (Piano et al. 1996, Porqueddu et al. 2003). 
Cocksfoot is a deeply-rooted medium to long lived highly productive grass species. It initiates growth early in the spring and due to the deep roots and access moisture in lower soil profiles, grows well during hot summer months as well during the autumn (Jacobs \& Siddoway 2007).

Investigations on subterranean clover as a component of sown pasture in recent years have shown that it has practical application for local climatic conditions in Bulgaria (Vasilev 2006, Vasileva et al. 2011, Ilieva \& Vasileva 2011, Vasileva \& Vasilev 2012ab, Vasileva 2014, 2015).

The aim of the present work was to evaluate nitrogen content in the yield of shoot and root biomass of subterranean clover and cocksfoot (sole and in mixtures) as affected by different levels of nitrogen supply.

\section{Materials and Methods}

Experiments were conducted at the Institute of Plant Physiology and Genetics, Sofia and Institute of Forage Crops, Pleven (2011-2014). Seeds of subterranean clover (Trifolium subterraneum L.) cultivar Antas and cocksfoot (Dactylis glomerata L.) cultivar Dabrava were germinated in Petri dishes at $25^{\circ} \mathrm{C}$ in a thermostat on wet filter paper for $24 \mathrm{~h}$ and were subsequently transferred to $2 \mathrm{~L}$ pots containing pure dry quartz sand. Sand moisture was sustained at $65 \%$ of full moisture capacity by watering to a defined weight. Mineral elements comprising Hellriegel nutrient solution were introduced in the pots at $1 / 2$ of full strength concentration, only $\mathrm{Ca}\left(\mathrm{NO}_{3}\right)_{2} \cdot 4 \mathrm{H}_{2} \mathrm{O}$ comprised $1 / 4$ of full strength concentration. Liophylized cell culture of the rhyzobial symbiont of subterranean clover (Rhizobium leguminosarum biobar trifolii) was introduced $72 \mathrm{~h}$ after sowing germinated seeds in the sand at $50 \mathrm{mg}$ cell dry weight per pot. Granulated inoculant for legumes was used which is effective for plants in the clover group, including subterranean clover, by Austrian technological

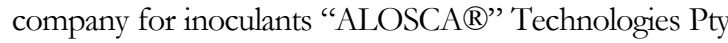
Ltd. Live cells from the strain were isolated by revitalization of YEM liquid medium (yeast extractmannitol-salts) and were also used as inoculant for subterranean clover. Culture was grown in a rotary shaker at $120 \mathrm{rpm}$ at $28^{\circ} \mathrm{C}$ until exponential growth phase was reached and concentration of bacteria was A600 - 0.9 ( $10^{8}$ cells $\left./ \mathrm{ml}\right)$. After $48 \mathrm{~h}$ of germination the seedlings were transferred to $1.2 \mathrm{~L}$ pots and grown as hydroponic cultures on Hellriegel nutrient solution containing the following minerals at full strength concentration in $\mathrm{g} / \mathrm{L}: \mathrm{KCl}-0.075, \mathrm{KH}_{2} \mathrm{PO}_{4}-0.136$, $\mathrm{MgSO}_{4}-0.060$, and micronutrients in mg/L: Fe-EDTA - 25, B - 0.6, Cu - 0.05, Zn - 0.05, Mn - 0.4 and pH 6.5 with continuous aeration, illumination of $250 \mu \mathrm{mol} /$ $\mathrm{m}^{2} / \mathrm{s}$ at $23^{\circ} \mathrm{C}$ in a growth chamber. Nitrogen concentrations were $\mathrm{N} 1=0.125 \mathrm{mM}$ and $\mathrm{N} 2=1.25$ $\mathrm{mM}$. The following variants of plants combinations were tested: subterranean clover $-100 \%+\mathrm{N} 1$; subterranean clover $-100 \%+\mathrm{N} 2$; cocksfoot $-100 \%$ $+\mathrm{N} 1$; cocksfoot $-100 \%+\mathrm{N} 2$; subterranean clover + cocksfoot $(50: 50 \%)+\mathrm{N} 1$; subterranean clover + cocksfoot $(50: 50 \%)+\mathrm{N} 2$. Water cultures were grown in a growth chamber with $12 / 12 \mathrm{~h}$ light/dark photoperiod, at $23^{\circ} \mathrm{C}, 150 \mu \mathrm{mol} / \mathrm{m}^{2} / \mathrm{s}$ light intensity, $65 \% \mathrm{RH}$ air humidity. After 40 days of growth under these conditions plants were collected and the following parameters were analysed: fresh shoot biomass (g/ plant), fresh root biomass ( $\mathrm{g} /$ plant), dry shoot biomass (g/plant) and dry root biomass (g/plant) dried at $60^{\circ} \mathrm{C}$. Dry plant material was used for quantification of total nitrogen content by Kjeldahl (as percentage of absolute dry matter) in shoots and roots (AOAC, 1990); nitrogen in yield of dry shoot mass (productivity of dry shoot mass multiplied by the percentage of nitrogen), expressed in $\mathrm{N}, \mathrm{g} / \mathrm{kg}$ dry shoot mass; nitrogen in yield dry root mass (productivity of dry root mass multiplied by percentage of nitrogen) in $\mathrm{N}, \mathrm{g} / \mathrm{kg}$ dry root mass, nitrogen in plant biomass yield (the sum of nitrogen in dry shoot + dry root biomass yield) in $\mathrm{N}, \mathrm{g} / \mathrm{kg}$ dry biomass. Nitrogen Use Efficiency (NUE) was calculated as suggested by Bowen and Zapata (1991), i.e. NUE $(\mathrm{g} / \mathrm{mM})=$ fresh biomass $(\mathrm{g} /$ plant $) /$ applied $\mathrm{N}$ $(\mathrm{mM})$. The share of nitrogen in dry shoot biomass and nitrogen in dry root biomass yield was expressed as a percentage of total nitrogen in plant biomass yield (\%). Experimental data were statistically processed by the SPSS (2012) software.

\section{Results and Discussion}

In sole grown subterranean clover nitrogen content in dry shoot biomass yield (15.97 vs. $5.50 \mathrm{~g} / \mathrm{kg}$ dry mass) was almost three times higher when grown under high nitrogen level $\mathrm{N} 2$ in comparison to low nitrogen level N1 due to the formation of greater plant biomass (Table 1).

Subterranean clover and cocksfoot are crops with different type of nitrogen metabolism. Nitrogen accumulation in cocksfoot is the result solely of nitrate nitrogen assimilation through the roots due to the activity of nitrate reductase, while in subterranean clover two sources of nitrogen are available: nitrate nitrogen absorbed directly from the substrate and atmospheric nitrogen fixed by nitrogenase in the nodules.

In mixtures with cocksfoot this tendency was similar with nitrogen content in yield under N2 (12.67 vs. $3.60 \mathrm{~g} / \mathrm{kg}$ dry mass) being even more than three times higher in comparison to N1 owing to stimulated growth of subterranean clover. Nitrogen content in shoot biomass yield of sole grown cocksfoot was significantly increased under N2 and was by $42.1 \%$ greater than respective nitrogen content under $\mathrm{N} 1$ level. Increase in the mixtures with subterranean clover was considerable reaching $138.6 \%$ on account of the legume component. 
Table 1. $\mathrm{N}$ in shoot and root biomass yield of subterranean clover and cocksfoot (sole and in mixtures) under different nitrogen supply levels

\begin{tabular}{lccc}
\hline Variants & & $\mathrm{N}$ in dry shoot weight yield & $\mathrm{N}$ in dry root weight yield \\
\cline { 3 - 4 } & & \multicolumn{2}{c}{$\mathrm{g} / \mathrm{kg}$ dry mass } \\
\hline Subclover (100\%) & $\mathrm{N} 1$ & 5.50 & 2.93 \\
Subclover $(100 \%)$ & $\mathrm{N} 2$ & 15.97 & 7.49 \\
Cocksfoot $(100 \%)$ & $\mathrm{N} 1$ & 3.87 & 1.25 \\
Cocksfoot $(100 \%)$ & $\mathrm{N} 2$ & 5.50 & 1.50 \\
Subclover*+Cocksfoot $(50: 50)$ & $\mathrm{N} 1$ & 3.60 & 2.88 \\
Subclover+Cocksfoot (50:50) & $\mathrm{N} 2$ & 12.67 & 4.46 \\
Subclover+Cocksfoot (50:50) & $\mathrm{N} 1$ & 0.88 & 0.37 \\
Subclover+Cocksfoot (50:50) & $\mathrm{N} 2$ & 2.10 & 0.30 \\
SE (P=0.05) & & 1.86 & 0.85 \\
\hline
\end{tabular}

* The values in the table refer to the bolded crops

It is known that higher amounts of nitrogen in the soil inhibit processes of nodule formation and nitrogen fixation in legume plants (Streeter 1985a, 1985b, Becana \& Sprent 1987, Streeter 1993, 1998). A dynamic relationship exists between legume and grass component of the mixture in which absorption of soil nitrogen by the grasses reduces its inhibiting effect on nitrogen fixation. Accumulation of soil nitrogen due to biological nitrogen fixation leads to domination of the grass and decrease of nitrogen fixation (Ledgard \& Steel 1992). Competition for soil nitrogen in mixtures may have favourable effect on the processes of nitrogen fixation and accumulation of more nitrogen in the grass component (Ta \& Faris 1987, Ledgard \& Steel 1992).

Nitrogen content in dry root biomass yield was also changed under the influence of nitrogen supply level. In sole grown subterranean clover this parameter was by $155.6 \%$ greater under the high nitrogen level N2 due to stimulated growth of root biomass when more nitrogen was provided.

In sole grown cocksfoot nitrogen supply had relatively slighter impact on nitrogen content in root biomass yield in comparison to shoot biomass yield. In root biomass an increment of $20.0 \%$ was estimated regarding nitrogen content in yield under N2 conditions. Under controlled nutrition conditions in a growth chamber it was established that when it was in combination with subterranean clover, cocksfoot was inhibited by both nitrogen levels, although more markedly under the lower N1 level. This observation could be attributed to the different absorption of nitrogen in the two crops. Matsunaka \& Takahasi (2001) found that $\mathrm{N}$ absorption in cocksfoot was supported by higher root activity, $\mathrm{N}$ uptake per unit dry root weight and $\mathrm{N}$ uptake per unit root length. They also found that dry root weight, one of the parameters of root mass, was the principal factor responsible for difference in the $\mathrm{N}$ absorption among the grasses.

In mixtures greater difference were found in the subterranean clover component which showed a $54.9 \%$ increase under N2 level (for shoot biomass more than three times increase was observed).

Data for nitrogen content in total plant biomass yield showed that higher inorganic nitrogen supply caused almost three times increase in sole grown subterranean clover in comparison to the low N1 level (23.46 vs. $8.43 \mathrm{~g} / \mathrm{kg}$ dry mass) and this relation had similar ratio in the mixtures with cocksfoot (17.13 vs. $6.48 \mathrm{~g} / \mathrm{kg}$ dry mass) (Table 2).

Table 2. $\mathrm{N}$ in plant biomass yield (shoot + root biomass) of subterranean clover and cocksfoot (sole and in mixtures) under different nitrogen supply levels

\begin{tabular}{llc}
\hline Variants & & $\begin{array}{c}\text { N in dry shoot and dry root } \\
\text { weight yield }\end{array}$ \\
\cline { 2 - 3 } & & $\mathrm{g} / \mathrm{kg}$ dry mass \\
\hline Subclover $(100 \%)$ & $\mathrm{N} 1$ & 8.43 \\
Subclover $(100 \%)$ & $\mathrm{N} 2$ & 23.46 \\
Cocksfoot $(100 \%)$ & $\mathrm{N} 1$ & 5.12 \\
Cocksfoot $(100 \%)$ & $\mathrm{N} 2$ & 7.00 \\
Subclover*+Cocksfoot $(50: 50)$ & $\mathrm{N} 1$ & 6.48 \\
Subclover+Cocksfoot $(50: 50)$ & $\mathrm{N} 2$ & 17.13 \\
Subclover+Cocksfoot $(50: 50)$ & $\mathrm{N} 1$ & 1.25 \\
Subclover+Cocksfoot $(50: 50)$ & $\mathrm{N} 2$ & 2.40 \\
SE (P=0.05) & & 2.68 \\
\hline
\end{tabular}

* The values in the table refer to the bolded crops 
For cocksfoot nitrogen in plant biomass yield was also greater under the high inorganic nitrogen level $\mathrm{N} 2$ with a $36.7 \%$ increase compared to N1 in sole grown and even more obviously $(92.0 \%$ increase) in the mixtures.

Nitrogen use efficiency in sole grown crops was higher in subclover (Figure 1), where the improved nitrogen nutrition led to higher plant biomass accumulation (shoots and roots). It was related to assimilation of higher amount of mineral nitrogen through roots and assimilation to organic nitrogen through nitrate reductase. In separately grown cocksfoot, where accumulated nitrogen was a result only of the assimilation of nitrogen through the roots, the nitrogen use efficiency was lower. Different type of nitrogen metabolism in the two crops determined the nitrogen use efficiency.

Nitrogen use efficiency was highest in the mixed system because of successful competition between the two crops for the available nitrogen in the solution, which favoured nitrogen fixation.

Distribution of nitrogen in total plant biomass yield showed higher share of nitrogen in the shoot yield under higher nitrogen supply (Figure 2). Similar conclusions were also made by Kostov et al. (2009) for sainfoin.

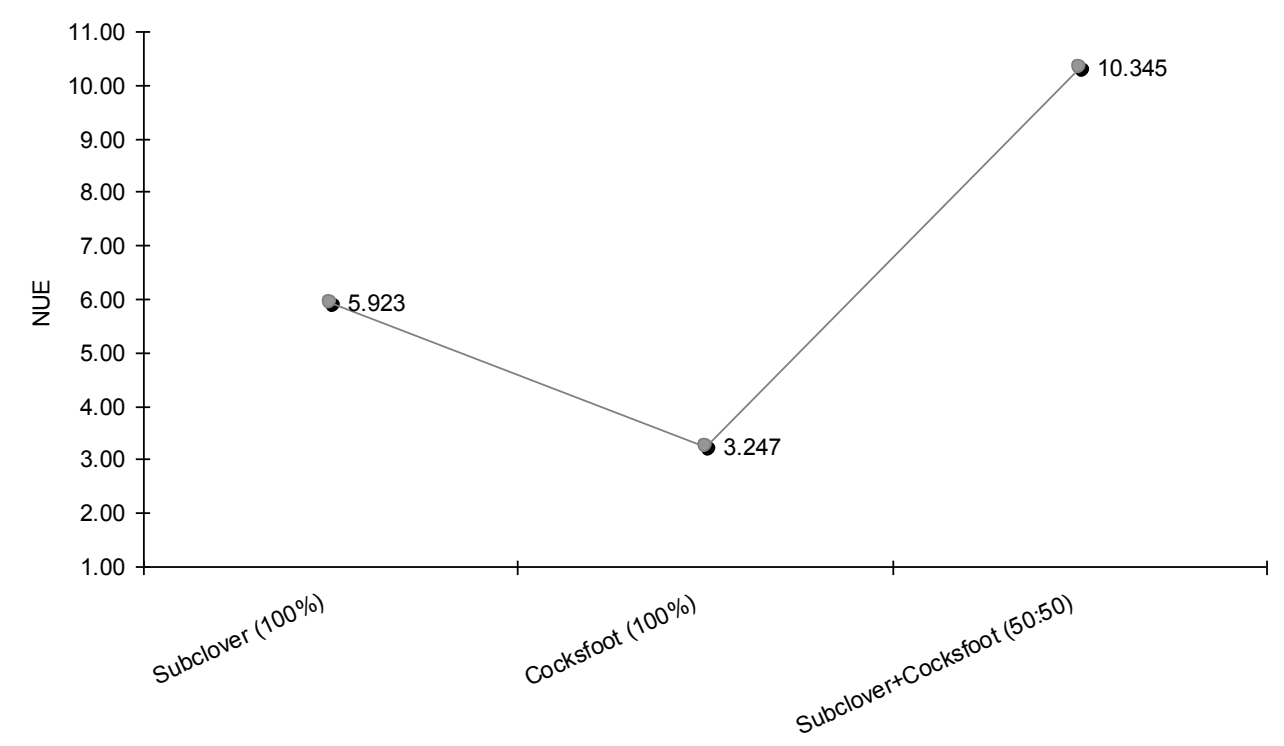

Figure 1. Nitrogen use efficiency (NUE) of subterranean clover and cocksfoot (sole and in mixtures)

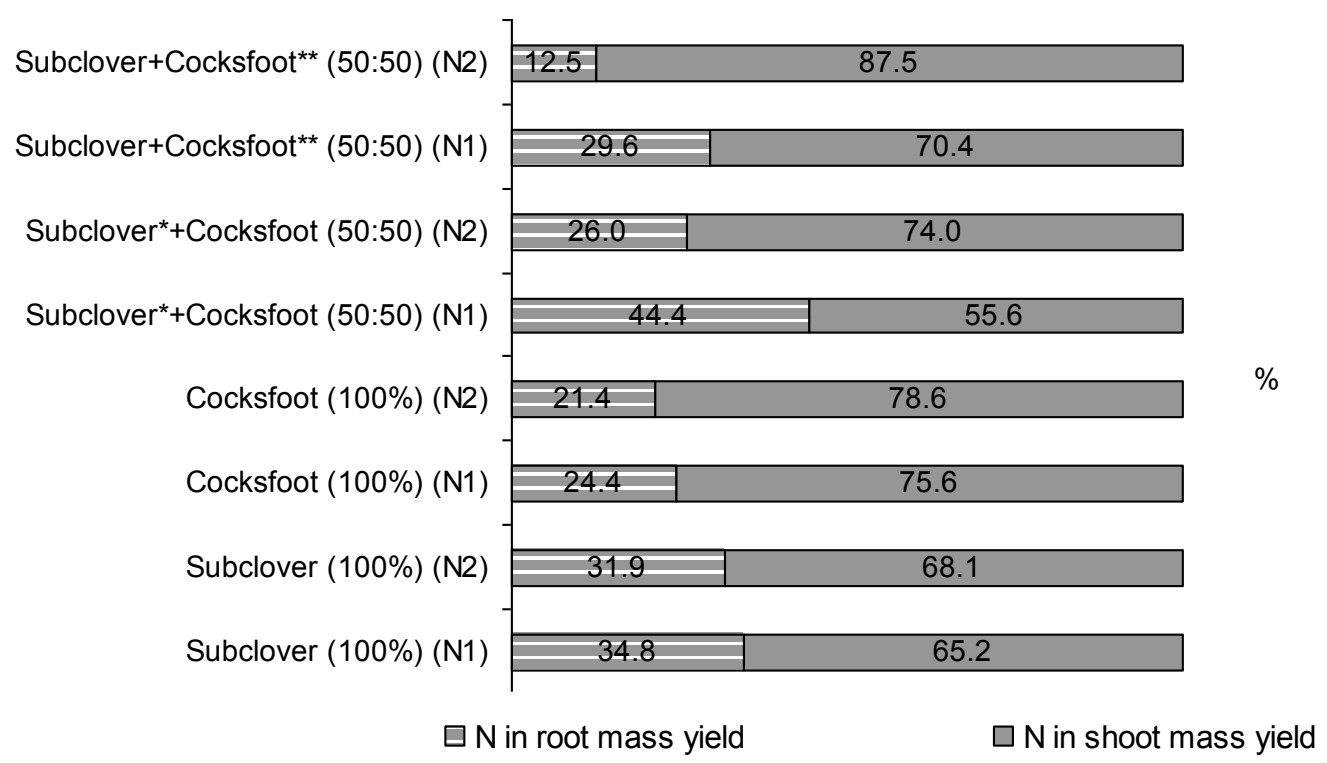

Figure 2. Distribution of nitrogen in shoot and root biomass yield of subterranean clover and cocksfoot (sole and in mixtures) under different nitrogen supply levels

(Values refer to: ${ }^{*}$ subterranean clover in mixture, ${ }^{* *}$ cocksfoot in mixture) 


\section{Conclusions}

Inorganic nitrogen concentration in subterranean clover and cocksfoot grown sole and in mixtures (50:50) had greater impact on nitrogen content in shoot biomass yield than in root biomass yield. Nitrogen content in shoot biomass yield of subterranean clover was three times greater under the high nitrogen level N2. Nitrogen content in shoot biomass yield of cocksfoot grown sole was by $42.1 \%$ higher under N2, and substantially greater (by $138.6 \%)$ in mixtures with subterranean clover. Nitrogen use efficiency was highest in mixture.

\section{References}

AOAC (1990). Official Methods of Analysis. 15 $5^{\text {th }}$ ed. Association of Official Analytical Chemists Arlington Va. K. Herlich (ed). Arlington Va. USA

Becana, M., \& Sprent, J. (1987). Nitrogen fixation and nitrite reduction in the root nodules of legumes. Physiol Plant., 70, 757-765.

Bowen, G. D., \& Zapata, F. (1991). Efficiency in uptake and use of N by plants. In: Proceeding Series Stable Isotopes in Plant Nutrition Soil Fertility and Environmental Studies. IAEASM 313/130, Vienna, Austria, 349-362.

Carneiro, J. P. (1999). Avaliação de luzernas anuais em solos á cidos, Estudo do efeito de alguns factores com vista ao melhoramento deplantas. Doutoramento em Engenharia Agronomica. Univercidade Técnica de Lisboa.

Frame, J., Charlton, J.F.L, \& Laidlaw, A.S. (1998). Temperate Forage Legumes. CAB International, Wallingford.

Graham, P.H. (2008). Ecology of the root-nodule bacteria of legumes. In: M.J. Dilworth, James E.K., Sprent J., Newton WE (eds). Nitrogen fixing leguminous symbiosis. Springer, Dordecht, The Netherland, pp. 23-58.

Ilieva, A., \& Vasileva, V. (2011). Study on nodulation and nitrate reductase activity in some mixtures. Journal of Mountain Agriculture on the Balkans, 14(3), 513-530.

Jacobs, J., \& Siddoway, J. (2007). Tame Pasture Grass and Legume Species and Grazing Guidelines, Plant Materials Technical Note Number MT-63 December 2007

Jarvis, S. C., \& Barraclough, D. (1991). Variations in mineral nitrogen under grazed grassland swards. Plant and Soil, 138, 177-188.

Kostov, O., Vasileva, V., Petkova V., Vladeva D., \& Mihailova O. (2009). Effect of mycorrhiza inoculation and elevated $\mathrm{N}$ levels on $\mathrm{N} 2$ fixation of sainfoin (Onobrychis sativa L.) assessed by isotope $15 \mathrm{~N}$ dilution technique. Journal of Mountain Agriculture on the Balkans, 6, 1337-1353.

Kusvuran, A., Ralice, Y., \& Saglamtimur, T. (2014). Determining the Biomass Production Capacities of Certain Forage Grasses and Legumes and their Mixtures under Mediterranean Regional Conditions. Acta Adv. Agric. Sci., 2, 13-24.

Ledgard, S. F., \& Steele, K.W. (1992). Biological nitrogen fixation in mixed legume/grass pastures. Journal Plant and Soil, 141(1-2), 137153.

Lelièvre, F., \& Volaire, F. (2009). Current and Potential Development of Perennial Grasses in Rainfed Mediterranean Farming Systems. Crop Science, 49(6), 2371-2378.

Luscher, A., Mueller-Harvey, I., Soussana, J.F., Rees, R.M., \& Peyraud, J. L. (2014). Potential of legume-based grassland-livestock systems in Europe: a review. Grass and Forage Science, 69, 206-228.

Matsunaka, T., \& Takahasi. H. (2001). Root weight as a principal factor responsible for difference in nitrogen absorption among cocksfoot (Dactylis glomerata L.), Meadow Fescue (Festuca elatior L.) and Timothy (Phleum pratense L.) during first growing period. Plant Nutrition, Developments in Plant and Soil Sciences, 92, 592-593.
Mihovski, Ts., \& Goranova, G. (2007). Westem European Varieties of White Clover (Trifolium repens L.) under Condition of Bulgaria. Journal of Balkan Ecology, 10, 407-410.

Pecetti, L., \& Piano, E. (1998). Leaf size variation in subterranean clover (Trifolium subterraneum L. sensu lato). Genetic Resources and Crop Evolution, 45(2), 161-165.

Pecetti, L., \& Piano, E. (2002). Variation of morphological and adaptive traits in subterranean clover populations from Sardinia (Italy). Genetic Resources and Crop Evolution, 49(2), 189-197.

Peeters, A., Parente G., \& Gall, A. (2006). Temperate legumes: keyspecies for sustainable temperate mixtures. Grassland Science in Europe, 11, 205-220.

Piano, E., Pecetti, L., Carroni, A.M. (1996). Climatic adaptation in subterranean clover populations. Euphytica, 92(1-2), 39-44.

Porqueddu, C., Parenteand, G., \& Elsaesser, M. (2003). Potential of grasslands. In: A. Kirilov, N. Todorov \& I. Katerov (eds.). Grassland Science in Europe, 8, 11-20.

Pozdisek, J., Henriksen, B., Ponizil, A., \& Loes A.K. (2011). Utilizing legume-cereal intercropping for increasing self-suffiency on organic farms in feed for monogastric animal. Agron. Res., 9, 343-356.

Pypers, P., Verstraete, S., Cong Phan, Thi., \& Merckx, R. (2005). Changes in mineral nitrogen phosphorus availability and saltextractable aluminium following the application of green manure residues in two weathered soils of South Vietnam. Soil Biol. Biochem., 37, 163-172.

Scholefield, D., \& Titchen, N.M. (1995). Development of a rapid field test for soil mineral nitrogen and its application to grazed grassland. Soil Use and Management, 11, 33-44.

Solomon, T., Pant, L.M., \& Angaw, T. (2012). Effects of Inoculation by Bradyrhizobium japonicum Strains on Nodulation, Nitrogen Fixation, and Yield of Soybean (Glycine max L. Merill) Varieties on Nitisols of Bako, Western Ethiopia. International Scholarly Research Network, ISRN Agronomy, doi:10.5402/2012/261475

SPSS (2012). SPSS Version 20.0. SPSS Inc., 233 S. Wacker Drive, Chicago, Illinois.

Streeter, J. (1985a). Nitrate inhibition of legume nodule growth and activity. I. Long-term studies with a continuous supply of nitrate. Plant Physiol., 77, 321-324.

Streeter, J. (1985b). Nitrate inhibition of legume nodule growth and activity. II. Short-term studies with high nitrate supply. Plant Physiol., 77, 325-328.

Streeter, J. (1998). Inhibition of legume nodule formation and $\mathrm{N}_{2}$ fixation by nitrate. CRC Critical Review, Plant Sciences, 7: 123.

Streeter, J.G. (1993). Translocation - A key factor limiting the efficiency of nitrogen fixation in legume nodules. Physiol. Plant., 87(4), 616-623.

Ta, T. C., \& Faris, M.A. (1987). Effects of Alfalfa Proportions and Clipping Frequencies on Timothy-Alfalfa Mixtures. II. Nitrogen Fixation and Transfer. Agron Journal, 79, 820-824.

Vasilev, E. (2006). Productivity of subterranean clover (Tr. subterraneum L.) in pasture mixtures with some perennial grasses for the conditions of Central North Bulgaria. Plant Science, S., 4, 149-152. (in Bulgarian)

Vasileva, V. (2014). Productivity of dry aboveground and root mass in mixtures. Journal of Mountain Agriculture on the Balkeans, 17(4), 956-969.

Vasileva, V. (2015). Botanical composition of swards with subterranean clover (Trifolium subterraneum L.). Bulletin of the Union of Scientists Rousse, Agriculture and Veterinary Medicine Sciences 7, 160-165. (in Bulgarian)

Vasileva, V., \& Vasilev, E. (2012a). Study on Productivity of some Legume Crops in Pure Cultivation and Mixtures. Agriculturae Conspectus Scientificus, 77, 91-94.

Vasileva, V., \& Vasilev, E. (2012b). Dry mass yield from some pasture mixtures with subterranean clover (Trifolium subterraneum L.). Journal of Mountain Agriculture on the Balkeans, Troyan, 15, 1024-1033.

Vasileva, V., Vasilev, E., \& Athar, M. (2011). Nodulation and root establishment of two clover species grown in pasture mixtures with wheatgrass. FUUAST Joumal of Biology, 1(1), 1-4.

Yakimova, Y., \& Yancheva, H. (1986). Phytocenological and ecological characteristics of some annual clovers in Strandja region, Plant Science, 23(4), 47-53. (In Bulgarian). 
Sadržaj azota u biljnoj biomasi podzemne deteline (Trifolium subterraneum L.) i ježevice (Dactylis glomerata L.) u odnosu na različite koncentracije neorganskog azota

\section{Viliana Vasileva $\cdot$ Konstantina Kocheva $\cdot$ Janet Mincheva Georgi Georgiev $\cdot$ Anna Ilieva $\cdot$ Claudio Porqueddu}

Sažetak: Sadržaj azota u biljnoj biomasi podzemne deteline (Trifolium subterraneum L.) i ježevice (Dactylis glomerata L.) je određen u odnosu na različite koncentracije azota. Biljke su uzgajane kao monokultura i u smeši kao simbiotrofne ili heterotrofne kulture pod kontrolisanim koncentracijama mineralnih elemenata u medijumu i inokulaciji rizobijalnim sojevima. Analizirane su dve koncentracije neorganskog azota: 0,125 mM (N1) i 1,25 mM (N2). Ogledne varijante su bile: podzemna detelina $(100 \%)+\mathrm{N} 1$; podzemna detelina $(100 \%)+\mathrm{N} 2$; ježevica $(100 \%)+\mathrm{N} 1$; ježevica $(100 \%)+\mathrm{N} 2$; podzemna detelina + ježevica $(50: 50 \%)+\mathrm{N} 1$; podzemna detelina + ježevica $(50: 50 \%)+\mathrm{N} 2$. Koncentracija neorganskog azota je imala veći uticaj na sadržaj azota u prinosu nadzemnog dela biljke nego na sadržaj azota u prinosu korenskog dela biljke u obe biljne vrste. Sadržaj azota u prinosu biomase čitave biljke podzemne deteline, uzgajane kao monokultura ili u mešavini sa ježevicom, bio je skoro trostruko viši pod režimom visoke koncentracije azota. Efikasnost iskorišćenja azota je bila najveća u smeši.

Ključne reči: azot, biomasa, Dactylis glomerata, ježevica, podzemna detelina, smeša, Trifolium subterraneum 